Bu makaleye atıfta bulunmak için/To cite this article:

AKYÜREK, R. UYLAȘ, S. (2021). İbn Kuteybe ve Garîbu'l-Hadîs Alanındaki Çalışmaları. Atatürk Üniversitesi

Sosyal Bilimler Enstitüsü Dergisi, 25 (4), 1659-1673.

\title{
İbn Kuteybe ve Garîbu'l-Hadîs Alanındaki Çalışmaları
}

\author{
Remzi AKYÜREK (*) \\ Sait UYLAŞ ${ }^{(* *)}$
}

Öz: Hz. Peygamber'in hadisleri, İslâm'ın Kur'ân'dan sonraki ikinci kaynağı sayılmaktadır. Dinimizle ilgili birçok hüküm ve bilgiler detayl olarak Kur'ân'da değil de hadislerde yer almaktadır. Bu hadislerde de birçok garip ve nâdir kelime geçmektedir. Dolayısıyla bu sözcükleri açıklamayı amaçlayan garîbu'l-hadîs dalı büyük önem kazanmıştır. Bu alana önemli katkılar sunan âlimlerden biri de İbn Kuteybe'dir. Bu çalışmada müellifin çok yönlü kişiliğinin daha iyi anlaşılmasını sağlayan garîbu'l-hadîs konusundaki katkıları ortaya konulmaya çalışılmıştır.

Anahtar Kelimeler: İbn Kuteybe, Garîbu'l-Hadîs, nâdir kullanışlı sözcükler.

\section{Ibn Kutayba and His Works in The Field of Gharîbu'l-Hadiths}

Abstract: The hadiths of the Prophet are considered the second source of Islam after the Qur'an. Many provisions and information about our religion are contained in the hadiths, not in the Qur'an. Many strange and rare words are also mentioned in these hadiths. Therefore, the branch of gharibulhadiths, which aims to explain these words, has gained great importance. Ibn Qutayba is one of the scholars who made important contributions to this field. In this study, it has been tried to reveal the contributions of the author on garîbu'l-hadith, which provides a better understanding of the multifaceted personality of the author.

Keywords: Ibn Kutayba, Ghareebu'l-Hadiths, rare useful words.

Makale Geliş Tarihi: 28.10.2021

Makale Kabul Tarihi: 16.12.2021

DOI: 10.53487/ataunisosbil.1015808

\section{I. İbn Kuteybe}

\section{A. Hayatı}

Ebû Muhammed Abdullah b. Muslim b. Kuteybe, 213/828 yılı Receb ayının ilk günlerinde Kûfe'de dünyaya geldi (İbnu'n-Nedîm, 1970: 42-43). Kaynakların çoğu, doğum yeri olarak Kûfe'yi verirken az bir kısmı da

\footnotetext{
*) Doktora Öğrencisi, Atatürk Üniversitesi Sosyal Bilimler Enstitüsü Arap Dili ve Edebiyatı Ana Bilim Dalı (e-posta: remziakyurek4@gmail.com) (D) ORCID ID. https://orcid.org/0000-00031659-9372

$\left.{ }^{* *}\right)$ Prof. Dr., Atatürk Üniversitesi Edebiyat Fakültesi Arap Dili ve Edebiyatı Bölümü (e-posta: saituylas@atauni.edu.tr) (D) ORCID ID. https://orcid.org/0000-0003-4048-2799

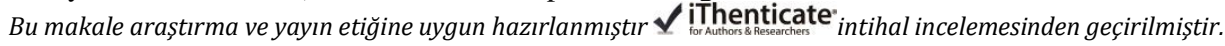


Bağdat'ta doğduğunu belirtmektedir. Büyük bir ihtimalle ailesi Kûfe'den Bağdat'a göç ettiğinden dolayı burada doğduğu söylenmiştir. Kaynaklar, İbn Kuteybe'nin Bağdat'ta yetiştiği konusunda ittifak halindedir. Müellif, Fars asıllı olup Araplaşmıştır (Kürd Ali, 1950: 88). Babası Mervli olduğundan ona da el-Mervezî, Dînever'de uzun bir süre kadılık yaptığından dolayı edDîneverî nisbeleri verilmiştir. Bazen de dedesi Kuteybe'ye nisbetle kısaca elKuteybî veya İmam Kutebî, Kûfe doğumlu olmasından dolayı da el-Kûfî denmiştir (Brockelmann, tsz: 222; Dayf, 1976: 611; Ferrûh, 1981: 329). Müellifin ailesinin Kûfe'den göç ederek Bağdat'a yerleştiği anlaşılmaktadır (İbn Kuteybe, 1923: 2-3). İbn Kuteybe, Bağdat'ta Câhiz'in (ö.255/869) ders halkasına katıldı ve onun bazı eserlerini bizzat ondan okuyarak icazetini elde etti (İbn Kuteybe, 1992: 199). Müellif birçok âlimin daha derslerine devam ederek ilim tahsil etmeyi sürdürdü. Halife Me'mûn (ö.218/833) döneminden itibaren Mutezile mezhebi devlet buyukleri tarafından itibar görmeye başladı. İbn Kuteybe de gençliğinde bu mezhebe sempati duymuş ve fikirlerini beğenmişti. Mutezile âlimlerinin akla ve felsefeye daha çok önem verip Allahu Teâlâ'nın sıfatları ve Kur'ân'ın müteşâbih âyetleri gibi tevile açık konularda İslâm'a aykırı yorumlarda bulunduklarını, dolayısıyla selef-i sâlihînin yolundan ayrıldıklarını görünce onlardan uzaklaşarak muhaddislerin ders halkalarına katılmaya başladı. Müellif, döneminin önde gelen hocalarından ilim tahsil ettikten sonra birçok sahada otorite oldu. Öğrendiklerini sonraki kuşaklara aktarmak amaciyla eserlerini kaleme almaya başladı ve bu dönemlerde devletin önde gelen önemli şahsiyetleriyle tanışarak onlarla ilişki kurdu. 236/850 yılında Arap edebiyatının dört ana kaynağından birisi sayılan Edebu'l-Kâtib'ini Halife Mütevekkil'in (ö.247/861) veziri 'Ubeydullah b. Yahya b. Hâkân'a (ö.263/877) ithaf etti. Müellif bunun karşılığında Dînever (el-Hamevî, 1977: 545) kadılığına atandı ve uzun bir müddet bu görevi yürüttüğü için kendisine ed-Dîneverî nisbesi verildi.

İbn Kuteybe, bir müddet Basra'da Dîvân-1 mezâlim başkanlığg gibi önemli bir görevi de yürütmüştür. Basra'nın 871 yılında Zencler tarafından yağmalanması sırasında bu şehirde bulunmaktaydı (İbn Kuteybe, 1973: 85). Müellif daha sonra Halife Mu'temid'in (ö.279/892) kardeşi Muvaffak (ö.278891) tarafından Bağdat'a davet edildi. Mu'temid halife olduktan sonra yetkilerini kardeşi Muvaffak'a devrederek zamanını oyun ve eğlenceyle geçirmiştir. İbn Kuteybe, Bağdat'a giderek el-Ma'ârif adlı eserini halifenin huzurunda okumuş, Muvaffak da onu on bin dinarla ödüllendirmiştir (Abdülbaki, 1990: 142-163). İbn Kuteybe daha sonra Bağdat'ta ikamet ederek eser telif etmeye ve öğrencilerine ders vermeye devam etmiş ve bu işi ölümüne kadar sürdürmüştür. Müellif, yediği yemekten sonra hastalanmış ve bir gün sonra 1 Receb 276/30 Ekim 889'da Bağdat'ta vefat etmiştir (Yazıc1, 1999: 145). 


\section{B. İlmî ve Edebî Kişiliği}

İbn Kuteybe, Abdullah b. Mukaffa' (ö.142/759) ve Câhiz'in ardından Arap edebiyatının en önemli temsilcisi sayılmaktadır. Lügat, şiir ve ahbâr konularında derin bilgiye sahip olan müellif, bu yönlerine ek olarak fikıh, tefsir, hadis, nahiv ve tarih sahalarında da otorite kabul edilmektedir (el'Uleyyânî, 1991: 64-65). Müellif, döneminin en büyük bilim merkezi olan Bağdat'ta yetişmiş olup, ilk dönemlerinde daha çok dinî bilimlerle iştigal ettiği anlaşılmaktadır. Bu bağlamda önce Garîbu'l-Kur'ân, Garîbu'l-Hadîs, Te'vîlu Muhtelifi'l-Hadîs ve Te'vîlu Muşkili'l-Kur'ân adlı eserlerini kaleme almışır. İlmî kişiliğinin en önemli tarafı, Arap edebiyatı tarihçisi ve eleştirmeni olarak taşıdığı özelliklerdir. Müellif aynı zamanda ilk tarihçilerden sayılmaktadır. Tarihçi yönünü en açık şekilde gösteren eseri el-Ma'ârif'tir. İbn Kuteybe bütün eserlerinde, hatta en küçük fasıllarda bile önceden belirlediği bir plana göre hareket etmiş, bu planında en kü̧̈ük bir boşluk ya da ihmale yer vermemeye çalışış̧ır. Paragraflarda, bölümlerde, fasıllarda ve cümlelerde düzen, dikkat, uyum ve insicam ve münasebetleri zincir halkaları gibi birbirine bağlayarak bütünlüğü sağlam bir konu ve düşünce akışı sağlamak, müellifin en önemli üslûbu olarak ortaya çımaktadır. Velûd olmakla birlikte, eserlerinde yüksek bir ilmi seviyeyi koruyabilen bir müellif olduğu muhakkaktır (Varol, 1986: 1-2).

İbn Kuteybe değişik sahalarda telif ettiği eserlerindeki yüksek seviyesi ve yeterliliği ile ilmî ağırlığını ispatlamış önemli bir simadır. Yaşadığı devredeki değişik fikirler ve görüşler ile münakaşalı konularda da eserler kaleme almıştır. Müellifin ilmî seviyesi, çok yönlü şahsiyeti ve değişik bilim dallarındaki yeterliliği nedeniyle hem kendi döneminde hem de daha sonraki dönemlerde insanların ondan faydalanmasını sağlayan mühim bir unsur olmuştur. İbn Kuteybe, bu yönüyle de haklı bir ün kazanmıştır. Eserlerini telif edişinden itibaren büyük bir hızla İslâm coğrafyasının bir ucundan diğer ucuna kadar geniş bir şekilde yayılması ve o zamanın imkânsızlıklarına rağmen yazma nüshalar halinde çoğaltılıp insanların rağbet ettiği eserler haline gelmesi, İbn Kuteybe'nin şöhretinin ulaştı̆ı boyutları gözler önüne sermektedir. Günümüzde dahi eserlerinin yazma nüshalarının dünyanın birçok merkezinde bulunması, bu hususu doğrulamaktadır. İbn Kuteybe'yi tarih sahasında da önemli bir âlim kılan neden ilk dönem müelliflerinden birisi olmasıdır. Belâzûrî (ö.279/892), Halife b. Hayyât(ö.240/854), Ebû Hanîfe edDîneverî(ö.282/895) gibi ilk dönem tarihçileriyle çağdaştır. Ehl-i sünnete mensup olması, döneminde mevcut olan birçok siyasî ve itikadî firkalardan uzak olması, onların yanlış ve batıl görüşlerine karşı objektif eleştiriler yöneltmesi vb. gibi sebebler yüzünden büyük itibar kazanmıştır. İbn 
Kuteybe'nin hangi mezhebi benimsediği konusunda değişik görüşler ortaya atılmasına rağmen Malikîliğe mensub olduğu kuvvetli bir ihtimal olarak görünmektedir (Varol, tsz: 1-10). Fakat Ahmed b. Hanbel (ö.241/855) ve mutlak müctehid sayılan hocası ibn Râheveyh'in (ö.233/848) görüşlerinden de etkilenmiştir (İbn Teymiyye, tsz: 129).

İbn Kuteybe Arap olmayan Müslüman unsurlar ve Araplar arasındaki kültür mücadelesi olan Şu'ûbiyye hareketine, Mutezile mezhebinin yükseliş ve çöküşüne şahit olduğundan tüm bunlar onun düşünce dünyasına ve eserlerinin muhtevasına etki etmiştir. Müellifin şöhreti öncelikle eş-Şi $r$ ve'ş-Şu 'arâ' adlı eserine yazdığ mukaddime ve burada tenkitle ilgili ele aldığ görüşlerinden kaynaklanmaktadır (Komisyon, 1999: 73). Birbirinden değişik birçok bilim dalıyla iştigal eden İbn Kuteybe'nin ilgisinin yoğunlaş̧tı̆ı alan dil ve edebiyattır, müellif bu sahada büyük bir otoritedir (el-Bağdâdî, 2001: 411). Bu önemli becerisini kelamcı ve filozofların Kur'ân ve hadis hakkında iddia ettikleri şüphe ve suçlamaları çürütmek için kullanmıştır (es-Sulemî, 2002: 221). Müellif bunlara ek olarak döneminin şerefli insanını ve iyi bir Müslüman yetiştirmeyi hedeflediğinden Ehl-i sünnetin takdirini kazanmış ve onun temsilcisi sayılmıştır (Miquel, 1983: 158). Böylece Câhiz'in Mutezile içindeki konumu gibi, İbn Kuteybe de Ehl-i sünnetin önemli âlimleri ve önderleri arasındaki yerini almayı hak etmiştir. $\mathrm{Bu}$ nedenlerle büyük bir itibar kazanmış, ona kötü söz söyleyen kimsenin zındık yani dinsiz olduğu, eserlerinin bulunmadığı evlerde hayır olmadığı belirtilmiştir (Komisyon, tsz.: 73).

İbn Kuteybe, özellikle eş-Şi 'r ve'ş-Şu'arâ' adlı eserinde ortaya koyduğu düşünceleriyle edebî tenkide önemli katkılarda bulunmuştur. Emevîler döneminden itibaren yetişen birçok âlim ve edip, kalitesi ne olursa olsun sadece eski şiirlere rağbet ediyor, güzel bile olsa yeni şiirlere önem vermiyordu. Mesela İbn Sellâm(ö.231/846), şairleri eskilikleri ve şiirlerinin kalitesine göre tabakalara ayırmaktaydı. Müellifin hocalarından el-Câhiz'in bu konudaki tutumu da hemen hemen İbn Sellâm'ın tavriyla aynı paraleldedir (Fadlullah, 2006: 80-81). İbn Kuteybe ise hocaları gibi şairleri tabakalara ayırmamış, şiir tenkidi konusunda yeni ve opjektif görüşler dile getirmiş, esas olan ölçünün şiirin eskiliği değil, kalitesi olduğunu vurgulamıştır. Müellif böylece görüşlerini cesaretle dile getirerek edebî tenkit alanında yeni bir çığır açmış ve bu konudaki taassuba son vermiştir. İbn Kuteybe'nin şiir ve şairler hakkındaki bu görüşleri günümüzde bile önemini korumaktadır. Müellifin şiir tenkidi konusunda ortaya koyduğu ölçüler, kendisinden sonra gelen birçok edebiyat eleștirmeni tarafindan da benimsenmiștir (el-Cundî, tsz: 349-352; Çetin, 1991: 288).

İbn Kuteybe döneminde mevcut olan dinî ve felsefî meseleleri Arap lügati sahasındaki eşsiz üstünlüğüyle halletmeye çalışış, Kur'ân-1 Kerim'i kendi batıl düşüncelerine uygun düşecek şekilde yorumlayıp tevil edenlerin görüşlerini filolojik deliller kullanarak çürütmüş, böylece tefsir bilimine de önemli katkılarda bulunmuştur (Birışık, 1999: 149). Müellif, bu alanda el- 
Muştebih mine'l-Hadîs ve'l-Kur'ân ve Tefsîru Sûreti'n-Nûr adlı eserlerini kaleme almış, böylece bu bilim dalında da varlığını ıspatlamıştır.

İbn Kuteybe hocası Câhiz'in belâgat sahasındaki işlevini ve düşüncelerini devam ettirip ileri boyutlara taşımış, belâğatle ilgili konuları gayet açık, net ve edebî bir üslûbla sunmuştur. İbn Kuteybe, içerik bakımından ileri boyutlarda takdim ettiği bu mevzuları dikkatli bir şekilde seçmiş, kolay ve anlaşılabilir kelimelerle aktarmasıyla diğer müelliflerden farklı olduğunu ortaya koymuştur. O, her ne kadar bu alanda hocası Câhiz'i taklit etmiş ise de gayet net ve açık bir üslûp kullanmayı tercih etmiştir (Karuko, 2018: 2-5). İbn Kuteybe değişik mevzular ve kullandığı beyan türlerini ele aldığı Te'vîlu Muşkili'l-Kur'ân adlı eserinde belâgat tarihi ve devrinin düşüncesini yansıtması açısından bir hayli dikkat çekmiştir (Arpa, 2011: 6). Müellif eserinde Kur'ân'ın i'câzına değinmiş, daha sonra da bölümlerini tek tek ele almış ve bunları geniş bir şekilde şerhetmiştir. Eser, mecaz, istiare, temsil, takdim, te'hir, kalb, hazf, ihtisar, tekrar, kinaye, ta'rîd gibi konulardan oluşmaktadır. İbn Kuteybe, mecazın Arapça'da yaygın bir şekilde kullanıldığını, Kur'ân'da da bulunmasından dolayı başka dillere tercüme edilemeyeceğini belirtmektedir. Âlimler, Kur'ân'ın başka dillere tercüme edilemeyeceği hükmünü verirken İbn Kuteybe'nin bu sözünü dayanak noktası olarak almışlardır. $\mathrm{Bu}$ bakımdan da müellif hicrî üçüncü asrın belâgat âlimlerinden birisi olup Arap belâgatına katkıda bulunmuş şahsiyetlerden biri sayilmaktadır (Meddâh, 2011: 11-70).

İbn Kuteybe Te'vîlu Muşkili'l-Kur'ân adlı eserinde belâgatle ilgili konulara ek olarak kırââtlerin müşkil problemlerine de değinmiş, o dönemin kırâât mefhumu konusunda bazı bilgilere yer vermiştir. $\mathrm{Bu}$ nedenle onun Te'vîlu Muşkili'l-Kur'ân'1 kırâât ilmi ve tarihi sahalarında da önemli bir kaynak durumundadır. İbn Kuteybe, bu eserinde kırââtler, mushaftaki sureler, lahn vb. gibi konularda ortaya atılan iddia ve şüpheleri ele alarak bunları tek tek çürütmüştür. Müellif, Hz. Peygamber'in 'Kur'ân'1n yedi lehçe üzerinde geldiğini'" bildiren hadisine yer vererek bunu şerhetmiş, böylece bunun bir ruhsat olduğunu, kırââtlerde görülen ihtilafların anlam çeşitliliği olduğunu, Arapça'nın herhangi bir vechine uygun olan farklılıkların lahn olarak görülemeyeceğini, Arapça'ya uymayan kırââtların mushafi yazan kâtibin hatası olduğunu ve bu yanlışların Kur'ân'a mal edilemeyeceğini ifade etmiştir (Temel, 2018: 303-311). Aslında İbn Kuteybe'nin bu sahalardaki çabaları kaleme aldığı Te'vîlu Muşkili'l-Kur'ân'1yla sınırlı kalmamıştır. Müellif, bu alanda Vucûhu'l-Kırâât, Kitâbu I'râbu'l-Kur'ân gibi eserlerini de telif etmesine rağmen maalesef bunlar günümüze ulaşamamıştır. 
İbn Kuteybe'nin, özellikle 'Uyûnu'l-Ahbâr gibi bazı eserlerinde izlediği emsalsiz metodla hocası Câhiz'i bile aştığı belirtilmektedir. Câhiz, eserlerinde anlaşılması zor bir dil kullanıyor ve istidrata çok yer verip konuyu dağıtıyordu. $\mathrm{Bu}$ yüzden istidrat denilince akla ilk gelen kişilerden birisi de şüphesiz Câhiz'dir (eş-Şek'a, 1991: 188). İbn Kuteybe ise nadiren garip kelimeler kullanıyor, eserlerinde yer verdiği garip ve zor kelimeleri, atasözlerini ve deyimleri açıklıyordu. Dolayısıyla insanların anlayabileceği sade bir dil kullanıyordu. İbn Kuteybe ayrıca eserlerini boş ve değersiz şeylerle doldurduğundan dolayı Câhizi eleştirmiş, bu konularda daha ciddi davranılması gerektiğini belirtmiş ve bu düşüncesini de gerçekleştirmiştir. Okuyucuların ciddi bilgilerin takibi sonucunda yaşayabilecekleri bıkkınlığı engellemek ve onları dinlendirmek için zaman zaman güldürücü fikra ve nüktelere de yer vermiştir. (Furat, 1996: 230-235).

İbn Kuteybe birçok sahada eser kaleme almasına rağmen sayıları tam olarak bilinmemektedir, bazıları da günümüze ulaşmamıştır. İmam enNevevî(ö. 676/1277), İbn Kuteybe'nin altmış civarında eseri olduğunu belirtmiştir (en-Nevevî, tsz: 13). Müellifin en önemli eserleri Edebu'l-Kâtib, eş-Şi 'ru ve'ş-Şu'arâ', Me'âni'ş-Sì'ri'l-Kebîr, 'Uyûnu'l-Ahbâr, el-Ma'ârif, Garîbu'l-Hadîs, Te'vîlu Muhtelifi'l-Hadîs, Garîbu'l-Kur'ân ve Te'vîlu Muşkili'l-Kur'ân'dır. İbn Kuteybe'nin eserleri çağdaşları Câhiz ve Ebû Hanîfe ed-Dîneverî’nin kitapları gibi döneminin birçok bilgilerini ihtiva etmektedir. 'Uyûnu'l-Ahbâr, el-Ma'ârif, el-Envâ', el-Meysir ve'l-Kidâh ve adlı eserleri Arap tarihi ve kültürüyle ilgilidir. Müellif, Kûfe dil âlimlerinin topladıkları bilgileri ve ahbârı derleyerek hem kâtipler hem de avam tabakası için Edebu'lKâtib'i kaleme almıştır. İbn Kuteybe'nin en önemli eserlerinden birisi olan 'Uŷ̂nu'l-Ahbâr, o dönemin en önemli edebî örneği sayılmaktadır. Birçok âlim ve müellif, İbn Kuteybe'nin bu eserinde takip ettiği üslûbundan etkilenmiş ve onu taklit etmişlerdir. Mesela Endülüslü âlim ve şair İbn Abdirabbih'in (ö.328/940) ünlü eseri el-'íkdu'l-Ferîd'i tamamen İbn Kuteybe'nin 'Uyûnu'l-Ahbâr' 1 tarzında kaleme aldığı belirtilmektedir (etTarâblusî, 1956: 145-147). Şüphesiz ki onu taklit eden sadece İbn Abdirabbih değildir. İbn Kuteybe, ilk dönem coğrafik eserlerin tasnif edilmeye başlandığ 1 devrede yaşadığından onun üslûb ve yöntemi bu sahanın âlimleri tarafından da taklit edilmiştir. Müellifin vefatından yaklaşık yirmi yıl sonra İbn Ruste'nin (ö.300/913) yazdığı el-A'lâku'n-Nefise adlı eserde bu durum açıç̧a görülmektedir. İbn Kuteybe el-Envấ adlı eserinde Araplar'ın coğrafya hakkındaki malumatlarını ortaya koymuştur (Miquel, 1983: 161-162).

\section{Garîbu'l-Hadîs Kavramı ve Bu Konuda Yapılan Çalışmalar}

Garibulhadis, hadis metinlerinde geçen garib ve nâdir sözcükleri konu edinen bilim dalı ve bu alanda kaleme alınan eserlerin ortak adı demektir (enNisâburî, 2003: 295). Hz. Peygamber, Yüce Allah tarafindan kendisine fesâhet ve belâgatin zirvesi olan Cevâmi'u'l-Kelim (Kandemir, 1993: 440) özelliğinin verildiğini, dolayısıyla insanların en fasih kişisi olduğunu ve Benî $\mathrm{Sa}^{\prime} \mathrm{d}$ 
kabilesinde yetiştiğini söylemektedir. Gerek Arabistan yarımadasında gerekse de diğer bölgelerde değişik birçok kabile yaşamakta idi ve bu kabilelerin lehçeleri de birbirinden farklıydı. Bu durum, Arapça'nın zengin dil hazinesinin doğal bir sonucudur. Hz. Peygamber'in bu kabilelere mensup insanlarla gerçekleştirdiği diyaloglarda ve yaptığı diğer konuşmalarında birçok garib kelime bulunmaktaydı. O dönemde yaşayan insanlar bu kelimelerin çoğunun anlamına vakıftılar. Anlayamadıkları sözcükleri ise Hz. Peygamber'e sorarak manalarını öğrenmekteydiler. Sahâbe ve tâbiîn döneminden itibaren İslâmî fetihlerin birçok bölgeyi kapsaması; İranlılar, Nabatîler, Türkler ve Rumlar gibi değişik milliyetlere mensup insanların Müslüman olmasıyla beraber lahn dediğimiz dil hataları çoğalmaya başladı. Zamanla da birçok kelime daha az kullanılmaya başlandı, bu nedenle nâdir ve garib bir hale geldi. Ayrıca birçok yabancı sözcük de Arapça'ya girdi. Bilindiği gibi İslâm'ın Kur'ân'dan sonraki ikinci ana kaynağı Hz. Peygamber'in hadisleridir. Kur'an'da hiç bulunmayan ya da detaylı olarak açıklanmayan bazı konular hadislerde ele alınmıştır. Hz. Peygamber'in sözlerinde garip ve nâdir kelimeler bulunduğundan bu tür hadislerin ele alınıp açıklanması büyük önem arzetmiş ve zaruri bir hale gelmiştir. Âlimleri bu sahada eser tedvin etmeye iten önemli bir sebeb de oluşmaya başlayan ve dil tahrifatları da diyebileceğimiz lahnin önüne geçmekti. Bu yüzden bazı âlimler, tüm emeklerini bu işe hasrettiler. Mesela Ebû 'Ubeyd el-Kasım b. Sellâm'ın (ö.224/838) sahanın temel eserlerinden biri olan Garîbu'l-Hadîs'inin kırk yıl süren geceli-gündüzlü çabalarının ürünü olduğu belirtilmektedir (İbnu'l-Esîr, (tsz.):3-9). Ebû 'Ubeyd'den önce ve sonra da birçok âlim bu nedenlerden dolayı eserler kaleme almışlardır. Garîbu'lhadîs üzerinde duran ilk âlimlerin tâbiînden sonra gelen tebe'u't-tâbi'în neslinden Mâlik b. Enes (ö. 179/795), Şu‘be b. Haccâc (ö. 160/776) ve Sufyân es-Sevrî (ö. 161/778) gibi muhaddisler olduğu ifade edilmektedir. Zamanla bu ilim sahası genişlemiş, sahâbî ve tâbiînin sözlerinde geçen garib kelimeler de açıklanmaya başlanmıştır. Bu sahada eser kaleme alan ilk âlimin el-Halîl'in öğrencisi Nadr b. Şumeyl el-Mâzinî (ö. 203/817) olduğu belirtilmektedir (enNîsâbûrî, 2003: 295-297; İbnu'n-Nedîm, tsz: 57). Bazıları ise Ebû 'Ubeyde Ma'mer b. Musennâ'nın (ö. 210/825) bu sahada eser telif eden ilk kimse olduğunu iddia etmektedir. Özellikle Abbâsîler'in ilk dönemlerinde yaşayan birçok dil âlimi ve edip, garîbu'l-hadîs konusunda eser kaleme almışlardır. İbnu'n-Nedîm (ö. ö. 385/995), Asma‘î'nin (ö. ö. 216/831) Garîbu'l-Hadîs'inin 200 sayfa olduğunu ve es-Sukkerî’nin (ö. ö. 275/888) hattıyla yazılmış bir nüshasını gördügünü belirtmektedir. Sîbeveyh'in (ö. ö. 180/796) Kutrub lakabıyla bilinen öğrencisi Muhammed b. el-Mustenîr'in (ö. ö. 206/ 821), Ebû Zeyd el-Ensârî'nin (ö. ö. 215/830), Ebû 'Amr eş-Şeybânî’nin (ö. ö. 213828), Asma'î ve Ebû 'Ubeyde'nin dostu Ali b. Muğîre el-Esrem'in (ö. ö. 230/845), 
İbn Durustuveyh'in (ö. ö. 347/958), el-Ferrâ'nın (ö. ö. 207/822) ünlü öğrencileri Muhammed b. Kadîm ve Seleme b. 'Asım (ö. ö. 275/885), Ebû Bekr el-Enbârî’nin (ö. 328/940) babası Kasım b. Muhammed ve Gulâmu Sa'leb olarak bilinen Ebû Ömer ez-Zâhid (ö. 345/957) gibi âlimler garîbu'lhadîs konusunda eser telif etmişlerdir. Bu âlimlerin kaleme aldığı eserlerin çoğu da garîbu'l-hadîs ismini taşımaktadır (İbnu'n-Nedîm, tsz: 58-83). Buna rağmen telif edilen bu eserlerin çoğunun küçük çaplı oldukları, en kapsamlı ilk telifin Ebû 'Ubeyd el-Kasım b. Sellâm'ın (ö. 224/838) Garîbu'l-Hadis adlı eserinin olduğu belirtilmektedir. İbn Kuteybe de Ebû 'Ubeyd'in gözden kaçırdığı garib kelimeleri tesbit etmek için Garîbu'l-Hadîs'ini kaleme aldı. Bu telif, İbn Kuteybe'nin en hacimli eserlerinden biridir. Müelliften sonra Hamd b. Muhammed el-Hattâbî de (ö.388/998) her iki eserde yer almayan garib ve nâdir kelimeleri açıklamak amacıyla Garîbu'l-Hadîs'ini kaleme aldı. $\mathrm{Bu}$ eseri de âlimler tarafından büyük kabul gördü. Böylece Ebû 'Ubeyd, İbn Kuteybe ve el-Hattâbî'nin bu eserleri, garîbu'l-hadîs sahasının temel kaynakları sayıldı (el-Hattâbî, 1982: 4; et-Tanahî, tsz :398).

Garibulhadis ile ilgili kaleme alınan eserlerin, sözlük çalışmalarını önemli derecede etkilediği ve Arapça sözlük telif edenlerin bu tür eserlerden bir hayli faydalandıkları belirtilmektedir. Buna ek olarak müfessirler ve edebî eserleri şerh eden âlimler de eserlerinde garibulhadisle ilgili kitaplardan istifade etmişlerdir. Ebû Mansûr el-Ezherî, Tehzîbu'l-Luğa adlı hacimli sözlüğünü Ebû 'Ubeyd, Nadr b. Şumeyl (ö.204/820) ve İbn Kuteybe'nin Garîbu'lHadîs'lerinden yararlanarak telif etmiştir. Ünlü dilci İbn Fâris (ö.395/1004) Mu'cemu Mekâyîsi'l-Luğa'sında Ebû 'Ubeyd ve İbn Kuteybe'nin Garîbu'lHadîs'lerinden önemli ölçüde istifade etmiştir. İbn Sîde (ö. 458/1066) elMuhkem ve'l-Muhîti'l-A 'zam adlı sözlüğünde; İbn Manzûr (ö. 711/1311) ünlü eseri Lisânu'l-'Arab'nda İbn Kuteybe, Ebû 'Ubeyd ve İbnu'l-Esîr'in Garîbu'l-Hadîs'leri ve el-Herevî'nin el-Ğarîbeyn adlı eserlerinden önemli oranda nakiller yapmıştır. Ahmed b. Muhammed el-Feyûmî (ö. 770/1368), elMisbâhu'l-Munîr fì Ğarîbi'ş-Serhi'l-Kebîr'inde, el-Murtaza ez-Zebîdî (1205/1791), Tâcu'l-'Arûs adlı büyük sözlüğünde de aynı eserlerden yararlanmıştır (İbn Kuteybe, 1977: 23-32).

Âlimler, garîbu'l-hadîse dair kaleme aldıkları eserlerinde birkaç yöntem izlemişlerdir:

1- Ebû 'Ubeyd ve İbn Kuteybe gibi âlimler, hadis metinlerinde geçen garip kelimeleri şerhederken alfabetik bir sıralama yapmamışlardır. Önce hadisleri konularına göre ayırmışlar, daha sonra da metinlerde geçen garib sözcükleri dil âlimlerinin sözleriyle, şiirlerle ve Arap atasözleriyle açıklamışlardır.

2- Bir grup âlim ise, içinde garib kelimeler geçen hadisleri tesbit ederek bunları alfabetik bir sıralamaya tabi tutmuştur. $\mathrm{Bu}$ yöntem sayesinde aranan kelimelere daha hızlı ve rahat bir şekilme erişebilme imkânı sağlanmaktadır. Ebû 'Ubeyd Ahmed b. Muhammed el-Herevî'nin (ö. 401/1011) el-Garîbeyn'i ve ez-Zemahşerî’nin (ö. 538/1144) el-Fâik fì Garîbi'l-Hadîs'i ve Mecduddîn 
İbnu'l-Esîr'in (ö. 606/1210) en-Nihâye fî Garîbi'l-Hadîs ve'l-Eser'inin bu şekilde tasnif edildiği belirtilmektedir.

3-Bir diğer yöntem ise birçok garib ve nâdir kelimeler ihtiva eden bazı hadislerin ele alınarak şerhedilmesidir. Ebû Bekr İbnu'l-Enbârî'nin (ö. 328/940) Hz. Ayşe'nin babası Hz. Ebû Bekir'i nitelediği hadisi de bu yöntemle ele alınmıştır. Kadı İyâd'ın Buğyetu'r-Râid limâ Tedammenehu Hadîsi Ummi Zer' minel-Fevâid adlı eserinin de bu türden oldu ifade edilmektedir. Hz. Ali'nin Hz. Peygamber'i nitelediği hadisini de birçok garib kelime ihtiva ettiğinden bu yönteme örnek olarak vermek mümkündür.

4- Bazı âlimler de metinlerinde nâdir ve garib sözcükler bulunan uzun hadisleri, sahâbî ve tâbiînin sözlerini ele alarak şerhetmişlerdir. Mecduddîn İbnu'l-Esîr'in Menâlu't-Tâlib fí Şerhi Tivâli'l-Ğarâib adlı telifi, bu yöntemle kaleme alınan eserlerdendir (et-Tanâhî, tsz: 398-399).

\section{III. İbn Kuteybe'nin Garîbu'l-Hadîs Konulu Eserleri}

Bilindiği İbn Kuteybe, Arap edebiyatı ve nesrinin en büyük temsilcilerinden olup dil, şiir, ahbâr ve Eyyâmu'l-'Arab gibi sahalarda tartışılmaz bir otoritedir (ez-Zehebî, 1983: 295-301; es-Suyutî, 1979: 63). Müellif ayrıca tarih, nahiv, fikıh, hadis ve tefsir gibi sahalarda da önemli bir mesafe katetmiş ve bu alanlarda da birçok eser kaleme almıştır. İbn Kuteybe, edebiyat ve hadis sahalarının ilk eleştirmenlerinden birisi sayılmaktadır. eşŞi'r ve'ş-Şu'arâ adlı ünlü eserinde şairler ve şiir konusunda yeni ölçüler ortaya koymuş, onun belirlediği bu esaslar kendisinden sonra gelen birçok edebiyat eleştirmeni tarafından da benimsenmiştir. Müellif, hadis gibi büyük öneme sahip bir sahanın da ilk eleştirmenlerinden biridir. Hz. Peygamber'in hadisleri İslâmiyet'in ikinci temel kaynağı sayılmaktadır. Tamamen anlaşılmaları ve onlardan fikhî hüküm çıkarılması için hadis metinlerinde yer alan garib ve nâdir kelimelerin açıklanması zaruridir. İbn Kuteybe, bu amaçla hocası Ebû Ubeyd el-Kasım b. Sellâm'ın Garîbu'l-Hadîs'ine almadığı garip ve nadir kelimeleri bir araya getirmek amaciyla Garîbu'l-Hadîs adlı eserini konularına göre kaleme almış, hadislerde yer alan garip ve nâdir sözcükleri tarihî olaylar, atasözleri ve şiirlerle şerhetmiş, fakat Ebû 'Ubeyd'in açıkladığı garip sözcüklere yer vermemiştir (Kandemir, 1991: 376). Müellif, ayrıca Ebû Ubeyd'in yanlış açıkladığını düşündüğü elliden fazla kelimeyi yeniden şerhetmek amacryla İslâhu Galati Ebî̀ 'Ubeyd fî̀ Garîbi'l-Hadîs adlı risalesini kaleme almıştır. Fakat bu hareketi ona çok pahalıya patlamıştır. Çünkü birçok bilgin, 'Ebû 'Ubeyd'in ilim ve takvada çok yüksek bir mevkide olduğunu düşünüyor ve onun da hata yapabileceğini kabul etmiyordu. Bundan dolayı bu âlimler, İbn Kuteybe'ye karşı birçok reddiye kaleme almış ve müellifi 
eleştirmişlerdir (İbn Kuteybe, 1983: 12-15; İbn Teymiyye, tsz: 143). İbn Kuteybe daha sonra bu sahadaki üçüncü eseri olan el-Mesâil ve'l-Ecvibe'yi kaleme almıștır. Eserde yer alan bu soru ve cevapların çoğu garîbu'l-hadîs ve dil hakkındadır (İbn Kuteybe, 1990: 17-26). Müellife ait Te'vîlu Muhtelifi'lHadîs adlı eserinin de onun bu çalışmalarının tamamlayıcısı olduğu belirtilmektedir (İbn Kuteybe, 1983; 11-70).

\section{A. Garîbu'l-Hadîs}

İbn Kuteybe'nin en hacimli eserlerinden olup üç ciltten oluşmaktadır. Eserin yaklaşık 140 yapraklık bir bölümünün kayıp olduğu ifade edilmektedir. (Varol, 2006: 6). Müellif, Ebû 'Ubeyd'in Garîbu'l-Hadîs'ini titizlikle inceledikten sonra onun hadislerde geçen birçok garib kelimeye yer vermediğini tesbit etmiş, bu nedenle Garîbu'l-Hadîs'ini kaleme alarak bu sözcükleri Kur'ân'dan, Arap meselleri ve şiirden seçtiği şevahidle açıklamıştır. İbn Kuteybe, bu eserinde Ebû 'Ubeyd'in açıkladığı kelimelere yer vermemiştir. Daha sonra el-Hattâbî (ö. 388/998) de Ebû 'Ubeyd ve İbn Kuteybe'nin tesbit edemedikleri garip kelimeleri açıklamak üzere Garîbu'lHadîs' ini kaleme aldı. Böylece Ebû 'Ubeyd el-Kâsım b. Sellâm, İbn Kuteybe ve Ebû Süleyman Hamd b. Muhammed el-Hattâbî el-Bustî'nin Garîbu'l-Hadîs adlı eserleri bu sahanın temel kaynakları haline geldi (et-Tanâhî, tsz: 398). Ebû 'Ubeyd ve İbn Kuteybe'nin Garîbu'l-Hadîs isimli eserleri el-Ğarîbeyn adı altında büyük üne kavuşmuştur. İbn Kuteybe, Garîbu'l-Hadîs'ini kendisinden önceki müfessirlerin ve dil âlimlerinin eserlerinden derlediğini, onların çizgisinden ayrılmadığını ve metodlarına göre kaleme aldığını belirtmektedir. Müellif, Garîbu'l-Hadîs'inde hadis metinlerinde geçen garip kelimelerin köklerini ve türetiliş yöntemlerini belirtmiş, onları Arap atasözleri, şiirler, ünlü simaların sözleri ve kısa ahbâr ile ortaya koymuş, kelimelerin benzerlerini zikrederek doyurucu bir şekilde açıklamalara yer vermiştir. İbn Kuteybe, Garîbu'l-Hadîs'inde önce fikhî eserlerde yer alan garib kelimeleri açıklar, daha sonra ise hadis metinlerinde geçen nâdir sözcükleri şerheder. Ayrıca çelişkili gibi görünen hadisleri uzlaştırır. Ardından sahâbe, tâbi'în, tebe'u'ttâbi'în, Emevî halifelerinin, valilerin ve bazı kadınların konuşmalarında geçen garip kelimeleri şerheder. İbn Kuteybe, söyleyenleri belli olmayan hitabelerde geçen garip sözcükleri şerhederek eserini bitirir. Müellifin bu eseri, özellikle kendisinden gelen birçok müfessir ve dil âlimi için önemli bir kaynak teşkil etmiş̧ir. Garîbu'l-Hadîs, lügatle ilgili önemli miktarda tenkitler ihtiva ettiğinden bu sahada da büyük önem kazanmıştır. Garibulhadis alanında İbn Kuteybe'den önce de birçok eser kaleme alınmasına rağmen maalesef bunlar günümüze gelmemiştir. Müteahhir âlimler, bu tür eserlerden bir hayli yararlanarak kitaplarını telif etmişlerdir. ez-Zeccâcî (ö. 340/952), Mecâlisu'l'Ulemâ'sında, Hamza el-İsfahânî (ö. 360/971), et-Tenbîh 'alâ Hudûsi't-, Ebû Mansûr el-Ezherî (ö. 370/980) Tehzîbu'l-Luga'sinda, , İbn Fâris (ö. 395/1004), es-Sahîbî ve Mu'cemu Mekâyîs'inde, Ebû 'Ubeyd el-Herevî (ö:401/1011), elĞarîbeyn'inde, Ebû Hilâl el-'Askerî (ö. 400/1009) de Cemheretu'l-Emsâl ve et-Talhîs fî Ma'rifeti'l-Eşyâ'sında; eş-Şerif er-Radî (ö. 406/1015) el- 
Mecâzâtu'n-Nebeviyye'sinde, kardeşi eş-Şerif el-Murteza (ö. 436/1044) Gureru'l-Fevâid ve Dureru'l-Kalâid ya da diğer adıyla el-Emâlî'sinde, Ebû 'Ubeyd el-Bekrî (ö. 487/1094), Mu'cemu Ma'ste'ceme ve Faslu'l-Makâl fî Şerhi Kitâbi'l-Emsâl'inde, Edebu'l-Kâtib'i şerheden İbnu's-Sîd (ö. 521/1127) el-íktidâb'1nda, Ebû Hafs en-Nesefî (ö. 537/1142), Talebetu't-Talebe'sinde, ez-Zemahşerî (ö. 538/1144) de el-Fâik fì Garîbi'l-Hadîs'inde, yine Edebu'lKâtib'in şârihlerinden el-Cevâlikî de (ö. 540/1145) el-Mu'arreb'inde, Kemâluddîn el-Enbârî (ö. 577/1181) Nuzhetu'l-Elibbâ'sında, İbnu'l-Cevzî (ö. 597/1201), Garîbu'l-Hadis'i ve Zâdu'l-Mesîr adlı tefsirinde, İbnu'l-Esîr (ö. 606/1210), en-Nihâye fî Ğarîbi'l-Hadîs ve'l-Eser'inde; Yakut el-Hamevî (ö. 626/1229) ünlü eseri İrşâdu'l-Erîb'inde, Abdullatif el-Bağdâdî (ö. 629/1231), Garîbu'l-Hadîsi'l-Kebîr'inde, es-Sağânî (ö. 650/1252), el-'Ubâb'ında, İbn Ebi'l-Hadîd (ö. 655/1257), Şerhu Nehci'l-Belâğa'sında, İmam en-Nevevî (ö:676/1277) Tehzîbu'l-Esmâ' ve'l-Lugât'1nda, İbn Manzûr (ö. 711/1311) Lisânu'l-'Arab adlı eserinde, el-Kalkaşendî (ö. 821/1418) Suphu'l-A'şâ fî Sinâ'ati'l-İnşâ'sında ve ez-Zebîdî (ö. 1205/1791) ünlü sözlüğü Tâcu'l-'Arûs fî Şerhi Cevâhiri'l-Kâmûs'unda İbn Kuteybe'nin Garîbu'l-Hadîs'inden önemli oranda yararlanmışlardır. Özellikle tefsir, hadis, nahiv, lügat vb. alanlarında büyük bir otorite sayılan ez-Zemahşerî'nin ünlü eseri el-Fâik fî Garîbi'lHadîs'ini İbn Kuteybe'nin bu eserinden bir hayli yararlanarak kaleme aldığı belirtilmektedir (İbn Kuteybe, 1983: 21-89).

\section{B. Islahu Galati Ebî 'Ubeyd fî Garîbi’l-Hadîs}

Küçük çaplı bir eser (risale) olup İstanbul'da bulunan yazma nüshası otuz bir yapraktır. İbn Kuteybe, bu eserinde hocası Ebû 'Ubeyd el-Kâsım b. Sellâm'ın yanlış yorumladığını düşündüğü 53 kelimeyi yeniden şerh etmiştir. Müellif eserinin önsözünde herkesin hata yapabileceğini, Hz. Peygamber'in sahâbîlerinin de buna dâhil olduğunu belirterek amacının Ebû 'Ubeyd'i kötülemek olmadığını, sadece yanlışlarını düzeltmek istediğini belirtmiştir. Íslâhu Galat, lügat tenkidiyle ilgili ilk eserlerden birisi sayılmaktadır. $\mathrm{Bu}$ eser, İbn Fâris ve İbnu'l-Enbârî gibi bazı âlimlerin tepkisini çekmiş ve İbn Kuteybe'ye sert eleştiriler yöneltmişlerdir. Ebû Mansûr el-Ezherî, Tehzîbu'lLuğa'sında, Ebû 'Ubeyd Ahmed b. Muhammed b. Muhammed el-Herevî, elGarîbeyn adlı eserinde, Ebû Mansûr el-Cevâlikî el-Mu'reb mine'lKelâmi'lkelâmi'l-A'cemî'sinde, Zemahşerî ve İbn Manzûr gibi âlimler de eserlerinde İslâhu Galat'tan önemli ölçüde istifade etmişlerdir. Ebu'lMuzaffer Muhammed b. Âdem el-Herevî İslâhu Galat'1 şerhetmiştir. Eser ilk defa 1968 yılında “Aziz Yusuf Fakültesi Dergisi” içinde Fransız müsteşrik Gerard Lecomte tarafindan Beyrut'ta neşredilmiştir. Lecomte'un neşrinin hatalarla dolu olmasinedeniyle Abdullah el-Cebbûrî tarafindan İbn 
Kuteybe'nin hayatı, eserleri ve garîbu'l-hadîs sahasındaki çabalarıyla ilgili bir mukaddimeyle beraber 1983 yılında Beyrut'ta yeniden yayımlanmıştır (İbn Kuteybe, 1983: 10-15).

\section{C. el-Mesâil ve'l-ecvibe}

Tam ismi el-Mesâil ve'l-Ecvibe fi'l-Hadîs ve't-Tefsîr olup İbn Kuteybe'ye sorulan sorulara verdiği 190 cevabı ihtiva etmektedir. $\mathrm{Bu}$ sorular garibu'lhadis, tefsir ve lügat hakkındadır. Değişik birçok bölgeye mensup insanlar, İbn Kuteybe'ye mektup göndererek garîbu'l-hadîs, lügat vb. gibi konularda ona sorular yöneltmişlerdir. $\mathrm{Bu}$ bölgelerden bazıları, Semerkand, Herat ve Misır'dır. $\mathrm{Bu}$ durum ise İbn Kuteybe'nin sağlığında da bu bölgelerde tanındığını göstermektedir. Bazıları da müellifin Garîbu'l-Hadîs'inde bulamadıkları garib kelimelerin anlamını öğrenmek amacıyla bu soruları sormuşlardır. Bu sorulardan 46 tanesinin garîbu'l-hadîs, 52 adedinin sahâbî ve tâbi'înin sözlerinde bulunan garib ve nâdir sözcükler, 20 tanesinin yine hadis tefsiri, 15 adedinin de lügatle ilgili olduğu belirtilmektedir. Müellifin bu sorulara verdiği bazı cevapların üç veya dört sayfa, bazılarının bir veya iki, bazılarının ise birkaç satır tuttuğu ifade edilir. İbn Kuteybe, Garîbu'lHadîs'inde yer vermediği hadisleri bu eserine ele alarak onları şerhetmekte, hadis metinlerinde geçen garib kelimelerin sözlük anlamını verip köklerini belirtmektedir. Daha sonra Kur'ân, hadis, eski Arap şiiri, sahâbe ve tâbi'înin sözlerinden şevahide yer verir. Böylece hadislerdeki garib ve nâdir sözcükleri doyurucu bir şekilde açıklamış olur. İbn Kuteybe, bu eserinde bazen de Kur'ân'ı tefsir eder. Görüşlerine delil olarak hadislere, sahâbe sözlerine ve şiirlere yer verir. Zaman zaman da birbirine zit gibi görünen ayetleri uzlaştırır. Müellif ayrıca fikıh, kıraat, tarih, belagât ve nahiv gibi konulara da değinmekte; konuyla ilgili âyet ve hadislere, sahâbe ve tabiîn sözlerine ve Arap şiirinden şevahide yer vermektedir. Müellif, bu eserinde hadis terimlerine de yer verip onları açıklamış, ayrıca konuyla ilgili birçok mesel de kullanmıştır. İbn Kuteybe ayrıca bu eserinde Kur'ân'daki bazı âyetleri şerhetmekte ve çelişkili gibi görünenleri uzlaştırmaktadır. Müellif bunlara ilaveten kıble, abdest, dua vb. gibi fikıhla ilgili konuları ele almakta, bazen de bu tür lafızları inceleyerek onların aslını ve türetimiyle ilgili bilgileri aktarmaktadır. Zaman zaman da İslâm kültürü, nahiv, tarih ve mantık gibi değişik konular hakkında bilgilere yer vermektedir. Dolayısıyla el-Mesâil ve'lEcvibe, birçok konuyu irdelediğinden zengin bir kaynak eser durumundadır. $\mathrm{Bu}$ nedenlerden dolayı onun bu eseri büyük önem kazanmıştır. İbn Kuteybe, bu eserini Garîbu'l-Hadîs'te izlediği aynı yöntemle kaleme almıştır. Bu yüzden bazı araştırmacılar, bu eseri Garîbu'l-Hadîs'in bir zeyli gibi kabul etmektedir. el-Mesâil ve'l-Ecvibe'nin İbn Kuteybe'nin kaleme aldığı son eserlerden birisi olduğu belirtilmektedir (İbn Kuteybe, 1990: 5-27). Bundan hareketle bu eserin müellifin bu sahadaki ilmî birikiminin önemli bir ürünü olduğunu söylemek mümkündür. 


\section{Sonuç}

Hadis-i şerifler, İslâmiyet'in Kur'ân'dan sonraki ikinci temel kaynağıdır. Kur'ân'da açıklanmayan bazı konular hadislerde geçmektedir. $\mathrm{Bu}$ nedenle hadis metinlerinde geçen garip ve nâdir kelimelerin açıklanmasını amaçlayan garîbu'l-hadîs konusu büyük bir önem arzetmektedir. Bunun farkına varan âlimler, bu sözcükleri şerhetmek amacıyla kitap telifine başladılar. Bu alan hakkında kaleme alınan ilk çalı̧maların küçük çaplı oldukları, Ebû 'Ubeyd elKasım b. Sellâm'ın Garîbu'l-Hadîs'inin sahasının ilk ciddi eseri olduğu belirtilir. $\mathrm{Bu}$ eseri titiz bir şekilde inceleyen İbn Kuteybe, müellifin birçok garip ve nâdir kelimeyi gözden kaçırdığını gördü. $\mathrm{Bu}$ nedenle Garîbu'lHadîs'ini kaleme aldı, Ebû 'Ubeyd'in yanlış şerhettiğini düşündüğü kelimeleri açıklamak amaciyla da İslâhu Galati Ebî̀ 'Ubeyd fî Garîbi'l-Hadîs adlı risalesini telif etti. Ebû 'Ubeyd ve İbn Kuteybe'nin bu eserleri büyük bir boşluğu doldurarak sahalarının temel eserleri durumuna geldiler. $\mathrm{Bu}$ nedenle onlara el-Ğarîbeyn denildi. İbn Kuteybe, İslâm coğrafyasının değişik bölgelerinden kendisine mektuplarla gelen soruları ve cevaplarını bir araya getirerek el-Mesâil ve'l-Ecvibe adlı eserini oluşturdu. Böylece garîbu'l-hadîs sahasına önemli katkılarda bulundu. Ebû 'Ubeyd ve İbn Kuteybe'den sonra yetişen birçok âlim, bu eserlerden önemli oranda faydalanmışlardır. Şüphesiz ki bu çalışmalar lahnın daha çok yayılmasını engellemiş, hadislerin daha iyi anlaşılıp onlardan daha isabetli dinî hükümler çıkarılmasını kolaylaştırmışıtır. Garîbu'l-hadîse dair kaleme alınan eserler, Arapça sözlük telif eden âlimler için de vazgeçilmez kaynaklar haline gelmiştir. Tüm bunlara ilaveten birçok ünlü müfessir ve dil âlimi bu tür eserlerden bir hayli yararlanarak sayısız eser kaleme almışlardır. Şüphesiz ki garîbu'l-hadîs sahasına en çok katkıda bulunan âlimlerden biri de İbn Kuteybe'dir. Onun bu alanda telif ettiği eserler büyük bir boşluğu doldurmuş ve garîbu'l-hadîs sahasının temel kaynakları haline gelmişlerdir.

\section{Kaynaklar}

Abdulbâkî, A. (tsz). Min A'lami'l-'Ulemâi'l-'Arab fi'l-Karni's-Sâlisi'l-Hicrî, el-Muessesetu'l-Misriyye'l-'Amme li't-Te'lîf ve't-Terceme ve't-Tibâ'e ve'n-Neşr.

Arpa, A. (2011). İbn Kuteybe'nin Belâgat İlminin Teşekkülüne Katkıları. Şırnak Üniversitesi İlahiyat Fakültesi Dergisi, 2(3), 3.

el-Bağdâdî, H. (2001). Târîhu Bağdâd. Dâru'l-Ğarbi'l-İslâmî.

Birışı, A. (1999). İbn Kuteybe'nin Tefsir İlmindeki Yeri. DIA, İstanbul: Türkiye Diyanet Vakfı Yayın Matbaacılık ve Ticaret İşletmesi. 
Brockelmann, C. (tsz). Târîhu'l-Edebi'l- 'Arabî. Dâru'l-Ma'ârif.

Cundî, A. (tsz). İbn Kuteybe. el-Muessesetu'l-Mısriyye'l-'Amme li't-Te'lîf ve't-Terceme ve't-Tibâ'e ve'n-Neşr.

Çetin, N. M. (1991). Arap (Edebiyat). Türkiye Diyanet Vakfi İslam Ansiklopedisi (C. 13, ss. 376-378). TDV İslam Araştırmaları Merkezi.

Dayf Ş. (1976). Târîhu'l-Edebi'l-'Arabî el-'Asru'l-'Abbâsî es-Sânî. Dâru'lMa'ârif.

Fadlullâh, M. A. M. (2006). el-Kadâya'n-Nakdiyye beyne'l-Câhiz ve İbn Kuteybe min Hilâl Kitâbeyhimâ el-Beyân ve't-Tebyîn ve'l-Me'âni'l-Kebîr. Umdurmân Üniversitesi Yayınları.

Ferrûh, 'U. (1981). Târihu'l-Edebi'l- 'Arabî. Dâru el-'İlm li'l-Melâyîn.

Furat, A. S. (1996). Arap Edebiyatı Tarihi. İstanbul Üniversitesi Edebiyat Fakültesi Yayınları.

el-Hamevî, Y. (tsz). Mu 'cemu'l-Buldân. Dâru's-Sâdir.

el-Hattâbî, (1982). Garîbu'l-Hadîs. Dâru'l-Fikr.

İbnu'l-Esîr, (tsz). en-Nihâye fì Garîbi'l-Hadîs ve'l-Esereser. el-Mektebetu'lİslâmiyye.

İbn Kuteybe, (1973). Te'vîlu Muşkili 'l-Kur'ân. Dâru't-Turâs.

İbn Kuteybe, (1977). Garîbu'l-Hadîs. Irak Vakıflar Bakanlığı Yayınları.

İbn Kuteybe, (1992). 'Uyûnu'l-Ahbâr. Dâru'l-Kutubi'l-‘İlmiyye.

İbn Kuteybe, (1983). İslâhu Galati Ebî'Ubeyd fì Ğarîbi'l-Hadîs. Dâru'lĞarbi'l-İslâmî.

İbn Kuteybe, (1990). el-Mesâil ve'l-Ecvibe. Dâru İbn Kesîr.

İbnu'n-Nedîm, (tsz). el-Fihrist.

İbn Teymiyye, (tsz). Tefsîru Sûreti'l-İhlâs. Dâru't-Tibâ‘eti'l-Muhammediyye.

Kandemir, M. Y. (1991). Garîbu'l-Hadîs. Türkiye Diyanet Vakfi İslam Ansiklopedisi (C. 13, ss. 376-378). TDV İslam Araştırmaları Merkezi.

Karuko S. (2018). “ İbn Kuteybe ve Muberred Üzerinde el-Câhiz Etkisi”. Yakın Doğu Üniversitesi İslâm Tetkikleri Merkezi Dergisi. 4(1).

Komisyon, (1990). “Ibn Kuteybe”. el-Mevsû 'atu'l- 'Arabiyye el- 'Âlemiyye.

Kürd Ali, M. (1950). Kunûzu'l-Ecdâd. Dimaşk: Edvâ’u’s-Selef.

Meddâh, A. (2012). et-Tanzîru'l-Belâğ $̂$ 'inde İbn Kuteybe. Vehrân (Oran) Üniversitesi Edebiyat Fakültesi. 
Miquel, A. (1983). Cuğrâfiyyetu Dâri'l-İslâm el-Beşeriyye. İşbîliyye li'dDirâsât ve'n-Neşr ve't-Tevzî'.

en-Nîsâbûrî, H. (2003). Ma 'rifetu 'Ulûmi'l-Hadîs. Dâru İbn Hazm.

en-Nevevî, M. (tsz). Tehzîbu'l-Esmâi ve'l-Luğât. Dâru'l-Kutubi'l-‘ỉlmiyye.

el-'Uleyyânî, A. (1991). 'Akîdetu'l-İmâm İbn Kuteybe. Taif: Mektebetu'sSiddîk.

es-Suyûtî, C. (1979). Buğyetu'l-Vu 'ât. Kahire- Dımaşk: Dâru’l-Fikr.

es-Sulemî, Y. (2002). Tavzîfu İbn Kuteybe el-Luğa li'd-Difâ' 'ani'l-Kur'âni'lKerîm. Mekke: Ümmü'l-Kura Üniveritesi Yayınları.

eş-Şek'a, M. (1991). Menâhicu't-Te'lîf 'inde'l- 'Ulemâ'i'l-'Arab. Beyrut: Dâru el-'İlm li'l-Melâyîn.

et-Tanâhî, M. M. (tsz). Fi'l-Luğa ve'l-Edeb. Dâru'l-Ğarbi'l-İslâmî.

et-Tarâblusî, E. (1956). Hareketu't-Te'liff. Üniversitesi Yayınları.

Temel, A. (2018). İbn Kuteybe'nin Kırâat İlminin Bazı Problemli Konularina Yaklaşımı. Adana: II. Uluslararası Multidisipliner Çalışmaları Kongresi, 45 Mayis.

Varol, H. (1986). İbn Kuteybe ve Eserleri. Atatürk Üniversitesi İlahiyat Fakültesi Yayınları.

Varol, H. (2006). İbn Kuteybe ve Eserleri. Atatürk Üniversitesi İlahiyat Fakültesi Yayınları.

Varol, M. B. (2008). “İbn Kuteybe ve Tarihçiliği”. İslâmı̂ İlimler Dergisi. $3(2)$.

Yazıc1, H. (1999). “İbn Kuteybe”. DİA. Türkiye Diyanet Vakfı Yayın Matbaacılık ve Ticaret İşletmesi.

ez-Zehebî, (1983). Siyeru A 'lâmi’n-Nubelâ', Muessesetu’r-Risâle. 